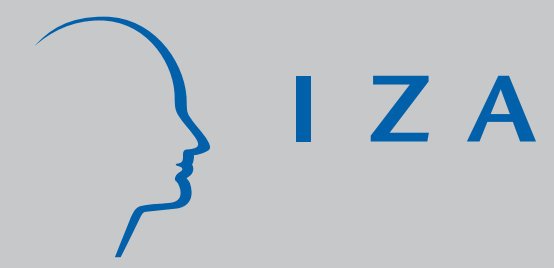

IZA DP No. 46

The Effects of Development on Migration:

Theoretical Issues and New Empirical Evidence

Ralph Rotte

Michael Vogler

June 1999 


\title{
The Effects of Development on Migration: Theoretical Issues and New Empirical Evidence
}

\author{
Ralph Rotte \\ Michael Vogler
}

Discussion Paper No. 46

June 1999

IZA

P.O. Box 7240

D-53072 Bonn

Germany

Tel.: +49-228-3894-0

Fax: +49-228-3894-210

Email: iza@iza.org

This Discussion Paper is issued within the framework of IZA's research area Internationalization of Labor Markets and European Integration. Any opinions expressed here are those of the author(s) and not those of the institute. Research disseminated by IZA may include views on policy, but the institute itself takes no institutional policy positions.

The Institute for the Study of Labor (IZA) in Bonn is a local and virtual international research center and a place of communication between science, politics and business. IZA is an independent, nonprofit limited liability company (Gesellschaft mit beschränkter Haftung) supported by the Deutsche Post AG. The center is associated with the University of Bonn and offers a stimulating research environment through its research networks, research support, and visitors and doctoral programs. IZA engages in (i) original and internationally competitive research in all fields of labor economics, (ii) development of policy concepts, and (iii) dissemination of research results and concepts to the interested public. The current research program deals with (1) mobility and flexibility of labor markets, (2) internationalization of labor markets and European integration, (3) the welfare state and labor markets, (4) labor markets in transition, (5) the future of work, and (6) general labor economics.

IZA Discussion Papers often represent preliminary work and are circulated to encourage discussion. Citation of such a paper should account for its provisional character. 
IZA Discussion Paper No. 46

June 1999

\section{ABSTRACT}

\section{The Effects of Development on Migration: Theoretical Issues and New Empirical Evidence*}

Empirical research on the determinants of international migration including the LDCs has so far neglected one important issue: the complex relationship of development and migration. Since the beginning of the 1990s several arguments have been discussed which hint at the possibility that progress in development of less developed regions might lead to more migration, even if income differentials to the potential destination regions decrease. This paper presents these arguments and tests them for the case of migration to Germany from 86 Asian and African countries from 1981 to 1995. The results confirm the importance of dissolving financial restrictions on migration, migration networks, and changes in the societal structure of the sending countries as well as the existence of a home preference. It is shown, however, that population growth does not necessarily lead to more international migration. The estimations also control for the political situation in the home countries and for institutional measures in the host country.

JEL Classification: F22, O15, O19

Keywords: Migration, international migration, developing countries, development

Michael Vogler

IZA

P.O. Box 7240

D - 53072 Bonn

Germany

Tel: +492283894117

Fax: +492283894210

e-mail: Vogler@iza.org

\footnotetext{
"We would like to thank Christoph M. Schmidt, Timothy J. Hatton and the participants of the international workshop "Hunger \& Migration: Historical and current perspectives" in Heidelberg, October 1997, for helpful comments and suggestions on earlier drafts.
} 


\section{Introduction}

There are a lot of theoretical hypotheses and models concerning the determinants of migration flows but only relatively few empirical insights in immigration from the developing world. This is mainly due to the bad data situation. Moreover, existing empirical studies have neglected one important aspect so far which has been seriously considered in the scientific discussion only since the beginning of the 1990s: the short and medium run effects of development on migration.

Examples of still basically unsolved problems of international migration from the LDCs include questions such as: Why has migration from the developing countries to the industrialized world been so small so far, despite the enormous differences in living conditions? What is the relevance of economic, political, societal and institutional factors concerning the observable migratory movements? Are determinants in the sending countries ("push migration") more important than conditions in the potential host countries ("pull migration")? How far must living conditions converge in order to make migration incentives disappear? Finally, there is also the question whether improving living standards in the Third World might result in an increase of migration flows to the industrialized countries.

The first part of this paper presents the arguments in the migration literature which give a possible explanation for the relatively small volume of immigration from developing countries, given the huge differences between Third and First World countries. For an overview on international economic and political migration flows see Segal (1993). Then there is a summary of basic theoretical aspects of the development-migration nexus. In order to prepare the empirical analysis, section 3 deals with the institutional framework of migration, some stylized facts about immigration to Germany, and the description of the data set. The estimations were based on a panel on immigration from 86 African and Asian countries to Germany during the period of 
1981-1995. Section 4 presents the estimation results. Section 5 summarizes the central findings.

\section{Development and migration - theoretical connections}

In his "laws of migration", Ravenstein $(1885,1889)$ summarized some fundamental insights which were based on relatively unsystematic empirical observation from a modern perspective, but are still of interest for further research today. Bähr et al. (1992, S.571f) give an overview of Ravenstein's most important conclusions: "1. The majority of migrants moves only over short distances, ..., 7. Most migrants are single adults, ..., 9. The magnitude of migration increases with industrial development and improvements in transport facilities, 10. The most important migration flows are directed from the countryside to the cities", and, last but not least, " 11 . The most important causes of migration are of an economic nature".

Meanwhile, broad theoretical foundations have evolved in the migration literature, which can explain these observations and reveal some further interesting relations. Since there are many survey articles on the issue (e.g. Straubhaar, 1988; Ghatak, Levine and Price, 1993; Bauer and Zimmermann, 1995; Vogler, 1999. For a more interdisciplinary view see Massey et al., 1993) the existing literature is reviewed here with a focus on the special problem why migration from the Third World to the industrialized countries has been so low despite high income differentials. For extensive references see the survey articles mentioned. Based on the considerations about factors impeding migration a closer look is then taken at the development-migration nexus. This aspect has only recently been particularly introduced into the literature. Again, for a more extensive review and references see e.g. Massey (1988) and Vogler (1999). 


\section{Migration-impeding factors}

Most economic models explaining individual migration behavior are still based on the so-called "neoclassical" approach even though its restrictive assumptions have been eased successively. Within this theoretical framework, the human capital approach (Sjaastad, 1962) interprets migration as a kind of investment by which individuals can employ their knowledge and abilities more profitable abroad than in their home country. In brief, migration takes place when the attainable future income in the host country is higher than the income in the home country plus migration costs. The "new economics of migration" (Stark and Bloom, 1985), however, emphasizes that migration of family members to various regions may decrease dependence on the situation in specific labor markets. This is especially important for developing countries where social security systems are hardly operative.

When looking at World Bank (1999) data, for example, one finds annual per capita incomes of USD 90 for Mozambique and USD 28,260 for Germany. On basis of the theoretical literature the following arguments which we will call "migration-impeding factors" can be used as possible explanations for the small volume of migration flows between First and Third World despite those enormous differences in living standards:

- Migration costs. The are a lot of costs connected to migration. First, there are the necessary direct expenditures for e.g. tickets. Moreover, there are also costs by income losses during the migration process and psychological costs, e.g. by separation from relatives and friends. These are probably quite high in case of migration between developing and industrialized countries, i.e. between fundamentally different social orders. The restrictive attitude of many western countries vis-à-vis immigration is also important in this respect since it complicates migration and thus results in higher migration costs as 
well.

- Expected unemployment in the host country. Apart from the labor market situation being rather tense in general in many industrialized countries, immigrants from developing countries also suffer from the problem that their human capital is hardly transferable. At least in the beginning, they tend to be qualified only for simple unskilled jobs in which employment opportunities are bad anyway. Aggravating difficulties in job search result from lacking knowledge of institutions, language and habits in the host country. Again the attitude of the industrialized countries plays an important role by impeding employment of migrant labor by institutional and legal restrictions. On the other hand one must also take into account that unemployment might not per se mean a complete lack of income. Social security systems in the industrialized countries are well established, at least far better than in most of the developing countries. In order to reduce migration incentives in this area, many western countries have also restricted access of migrants to social security benefits.

- Uncertainty. An important aspect which is partly connected to the arguments already given, is uncertainty. Potential unemployment but also other economic and non-economic aspects lead to migration being a risky business. The decision to migrate always implies the danger of being mistaken which may lead to an involuntary return or further migration. Acquisition of information in order to reduce uncertainty, however, is costly. No individual will be able or willing to spend unlimited resources on it, so uncertainty may impede migration. Again, one can assume that this is especially relevant for migration between two fundamentally different social systems where uncertainty is relatively high.

- Option of waiting. Migration in general and between developing and industrialized countries in particular is thus very costly. Investment in migration might be made in vain if the 
situation in the home country develops more favorably than expected or if the situation in the destination country deteriorates contrary to one's expectations. Therefore ist could be optimal not to migrate for the time being, but to collect more information and to await the further development at home and in potential destination countries. In principle, a decision can be repeatedly postponed until migration is in fact not profitable any more.

- Income valuation. A further question is whether higher future incomes in the destination country are really highly valued in the individual's decision process, or whether it is mainly short-term income differentials and migration costs which determine his decision. Another problem might be a higher valuation of income at home than income abroad. Similar to the costs of migration, this may be due to psychological causes.

- Relative income situation: According to the "new economics of migration", which builds on well-known standard results of group research in social psychology and sociology, migration incentives may not result from existing absolute income differentials but from the income position relative to a reference group. In brief, if one is poor among poor, incentives to migrate might be lower than if one is poor among (relatively) rich.

These microeconomic considerations enable us to draw some conclusions for the macro level although any aggregation implies a problem of mixing behavioral and distributive effects. Vogler (1999) explains this problem which is well-known from e.g. consumption theory for the case of migration, and shows the resulting difficulties of the empirical analysis of macro data. Nevertheless, microeconomics gives us at least some valuable hints for the macro level. For example, migration flows should be the smaller the higher the costs of migration, the higher unemployment in the destination country and the lower information flows from industrialized countries to LDCs. 


\section{Development and migration: Complex relations}

Even though actual migration flows to the industrialized countries are surprisingly low, considering the huge differences in development, most western countries aim at reducing the influx and the migration pressure. It is often assumed that convergence of living standards will successively lead to less migratory movements. Therefore a study by the US Commission (1991) attracted much attention, although it was basically just a synopsis of aspects already known. Its conclusion was that, due to trade liberalization within NAFTA and the corresponding development effects on Mexico, Mexican immigration to the United States would rise, not fall. Initiated by this report the connection of development and migration has attracted more and more scientific interest during the subsequent years. Five main arguments have been suggested as explanations for an increase of migration in the course of development:

- Dissolution of financial restrictions. The human capital approach assumes that necessary expenditures for migration (e.g. tickets) can be covered by savings or by current or future income. In the case of developing countries with in part extremely low incomes, however, it is not at all natural that sufficient financial resources are available for migration. Moreover, financial institution (if existing at all) will hardly be willing to give the potential migrant a credit. The only possible way would be the joint financing of migration of a family member within the framework of a group decision. No matter how, if some substantial fraction of the current population cannot migrate although it would be economically optimal, an increase in income through economic growth and development will dissolve those financial restrictions and lead to more migration (not taking into account potential incentive effects due to convergence in income).

- Population growth. Most LDCs are still mainly agricultural economies. It is well-known that a 
change from an agricultural to an industrial society leads to a period of demographic transition during which falling mortality rates result in high population growth. This implies two important consequences for migration. First, more persons automatically mean more potential migrants. Especially when strong cohorts reach employable age where in early years preparedness to migrate is highest, one would expect an increase of migration. Second, apart from this direct effect, there is an indirect effect via the labor market. In principle, an increase in labor supply leads to lower wages or to higher unemployment, which both increase migration incentives. Again, young people in the labor force are most concerned since the rise in labor supply happens in this specific labor market segment.

- Destruction of traditional order. Economic development also means societal change. Technological progress results in rising productivity in agriculture, a release of agricultural workers and a lower number of small peasants. Traditional ties to the rural areas are weakened and rural-urban migration increases, also fostered by rising labor demand in the newly industrializing conurbations. High internal migration in the LDCs has been in progress for decades and might be additionally strengthened by further development progress. In the course of this process one has to expect that higher general mobility will also lead to more international migration.

- Progress in communications and transport. Development also means more information. First, new technologies, including modern communications, are employed, and second, the education level of the population increases. Moreover, availability of various media and thus of information is higher in cities which absorb an ever-increasing part of the population. Another important point is the expansion of transport infrastructure and international contacts (e.g. by trade) which reduce costs and uncertainty, and thus may 
lead to higher migration.

- Network effects. If those factors have once initiated migratory movements, then network effects may cause a persistent or even reinforcing movement. Migrants' contacts to their home country reduce the costs and uncertainty for further potential migrants. Moreover, these contacts in the destination country facilitate accommodation and job search for follow-up migrants, which also increases migration incentives.

Apart from these effects which are potentially reinforcing international migration, development may also have some consequences reducing migration:

- Reduction of the income differential. This point is obvious and does not need further explanation. If in the course of development incomes in sending and receiving countries converge, migration incentives decrease ceteris paribus.

- Home preference. One aspect which is of special interest for the industrialized countries occurs if potential migrants valuate income at home with a greater weight than income abroad. In this case, development could lead to less migration incentives, even if the income differential remains the same or even rises up to a certain point.

Combining all these different arguments leads to a theoretical idea of an inverse u-shaped relationship between development and migration. Starting with very low income levels in the Third World, dissolving financial restrictions, population growth, societal change, improved communications and expanding networks will lead to increased migration to the industrialized countries in the short and medium run. In the long run, however, potential convergence of incomes and home preferences will cause migratory movements to fall.

This pattern of an inverse u-shaped connection of development and migration could be observed in European emigration in the 19th century. Most countries reached the maximum of 
emigration about 50 years after the beginning of industrialization. See Hatton and Williamson (1994) for an extensive analysis of the underlying factors of emigration. Concerning intraEuropean south-north migration, Faini and Venturini (1993) have shown the importance of dissolving financial restrictions and the existence of home preferences. Migration from developing countries to the western world, however, has not been empirically analyzed in a broader framework so far.

\section{Foundations of the empirical analysis}

This section presents some important and interesting points with regard to the estimations we have done in this paper. First, it is important to have a look at the institutional framework within migration takes place. States and governments have in principle a decisive influence on migration flows via their legal regulations. In the context of the institutional situation in Germany we also give a short overview of the most important facts about immigration from Europe and from outside of Europe. The second part of this section deals extensively with our data set and discusses the central problems with analyzing the basic questions of this paper.

\section{Institutional framework and stylized facts}

There are several regulations in international law which affect migration directly or indirectly. On top of them there is the Declaration of Human Rights, concerning labor migration the International Labor Organization (ILO) has issued a number of conventions, and refugee migration is dealt with in the Geneva Convention, together with the protocol of 1967 . For an extensive survey see e.g. Goodwin-Gill (1989) and Vogler (1999). As a whole, however, international law almost exclusively regulates the residence of migrants, not actual migration flows. This can be easily explained by the principle of national sovereignty which implies that 
states may decide autonomously about who is allowed access to their territory and who is not. In the course of creating the European Common Market and the abolition of intra-EU borders there have been some attempts to coordinate national legislations concerning immigration (see e.g. Vogler, 1999). Nevertheless, the European Union is still far away from a common migration policy. What is striking about the European countries' policies, however, is their double strategy. While the EU member states agree about the advantages of free movement within the Union, they try simultaneously to contain immigration from outside the Union as far as possible.

Within Europe, Germany is the country which has experienced the highest immigration during the recent decades (see e.g. SOPEMI, various issues, and Eurostat, various issues), although immigration has been mostly unwanted since the recruitment stop for guestworkers at the beginning of the 1970s. After the end of active recruitment there have been only few channels left for legal immigration from outside the EU: family reunification, application for asylum, special regulations for the acceptance of war refugees, specialists and students. Since the beginning of the 1990s there has also been legal temporary labor migration from east European countries. For citizens of developing countries only application for asylum and family reunification have been relevant; the number of "boat people" and students has remained neglectable. Until 1993, applying for asylum secured at least a temporary stay in Germany since the decision procedure normally took several years. Even in case of a negative decision, many people did not have to return home due to various humanitarian considerations.

Figure 1 shows that immigration to Germany from outside Europe has always been small if compared to intra-European inflows. Figure 2 splits the influx according to sending continents. From the end of the 1970s there was an increasing inflow from developing countries, with the influx from Asia being persistently higher than from Africa. For asylum seekers (Figure 3) the 
inflow from outside Europe has been relatively more important in comparison to total immigration. Nevertheless one can see that the huge immigration wave at the beginning of the 1990s was mainly an intra-European phenomenon. Its main causes were the demise of the Iron Curtain and the civil war in the Balkans. Figure 4 distinguishes asylum seekers according to sending continents. It is important to note that asylum seekers are also part of the numbers on total immigration, but because of different timing of registration one cannot calculate balances from the two statistics.

As mentioned earlier, there have been some restrictive measures concerning immigration in Germany. Since they are of high relevance for the empirical analysis we give a short description of the most important reforms which took place in 1987, 1991 and 1993. The central measure of the 1987 reform was an expansion of the temporary work ban for asylum seekers from two to five years. Moreover, asylum procedures were changed in several aspects which actually led to tightening up the regulations. In 1991, the work ban for asylum seekers was first reduced to one year and then abolished altogether half a year later. The 1993 reform was the most extensive one, resulting in an amendment of the German constitution and in a massive complication of asylum immigration. While previously, an application for asylum meant at least a temporary legal stay in Germany, persons arriving by land have in principle been excluded from the asylum procedure altogether, although immediate expulsion is often impossible. For a thorough survey see e.g. Vogler (1999).

\section{Data set and econometric model}

In general, for an empirical analysis of the development-migration nexus ordinary time series analysis is inadequate from the start. For, first, the necessary retrospective data on central factors is not available for longer periods for many LDCs. Second, no country, maybe with the 
exception of the southeast Asian "Tigers", has gone far enough through a fundamental development process which would give us a chance to analyze the long term relation between development and migration. In our case it seems more promising to look at a cross-section of different countries covering a far stronger variation in development stages than one single country could experience within a few decades. Since one cannot control for country-specific factors in a cross-section study, however, using a panel data set is more advantageous. For a survey of the advantages and an overview of existing panel studies on international migration see Vogler (1999).

In general, data availability for the analysis of international migration is very unsatisfying and so empirical evidence on the determinants of international migration is scarce so far. This is especially the case for migration from developing countries. Not only is information missing frequently but also existing data often is not comparable. ILO (1997) gives an extensive survey of the problems. Nevertheless, we have collected a dataset for a special part of the migration issue: international migration from 86 African and Asian countries into Germany. This dataset is first based on the total inflows (1981-1995), provided by the Federal Statistical Office relying on information by local registration offices. In Germany registration with the relevant local community is mandatory for every change of place of living. Second, we have information about numbers of asylum seekers (1984-1995), as published by the Federal Ministry of the Interior. As mentioned above, inflows also cover asylum seekers, but there might be greater time lags in registration in both statistics. In principle, leaving a local community (or Germany) must also be reported, and this information is also available. In practice, however, notices of departure are often omitted by persons leaving Germany, so that available numbers are not very reliable.

Our dataset covers immigration from most of the African and Asian LDCs. We look at countries from which Germany received immigrants, as well as those without any person 
coming. Unfortunately, the basic statistics available were not always perfectly broken down. Countries sending only few immigrants were combined as a residue. For 1984, for example, numbers on asylum seekers were broken down only for 19 of 86 countries, which nevertheless covered 98.1 percent of the influx. For 1995, it was for 77 out of 86 countries (100 percent). In the case of the total flow data the relation was not that positive: In 1981, numbers were broken down for only 54 countries, covering 96.2 percent of immigrants. For 1995, there was detailed information about 75 countries (99.6 percent). With these numbers, we considered it justifiable to set the number of immigrants from the countries that were not broken down to zero. The other possibility would have been to equally distribute the residual number on the countries that were not broken down. Actually, we made estimations under this hypotheses but results did not changed in a remarkable manner.

The dependent variable is migration rates which means that the number of inflows, and of asylum seekers respectively, was divided by the population of the sending countries. The first set of explanatory variables covers the influence of economic circumstances. As explained above, in principle, these include wages, the unemployment rate as a measure of occupation opportunities, but also information about the tax and social security systems. It is often hardly possible to obtain comparable data on different countries, and for the LDCs these numbers are not available at all in most cases. Like most empirical studies for international migration we therefore use Gross National Product (GNP) per capita as a crude proxy for different living standards. It is eventually desirable to adjust these numbers to different costs of living in the countries, but unfortunately there is only few information on these. As SOEC (1985) has shown for a range of African countries, adjustment for purchasing power parities differently increases income of the LDCs, but the relative position of the countries remains basically unchanged. On the other hand one may suppose that many potential migrants are not informed about the cost-of-living 
differences and thus do not fully include this information in the decision making process. Because of the bad data situation and the points mentioned against the purchasing power argument we mainly trust in an uncorrected GNP per capita ratio of the relevant sending country and Germany. It is to cover the supposed effect of decreasing migration incentives with converging living standards. However, we have also run additional estimations with purchasing power parities from the Penn World Tables (see Summers and Heston, 1991), which has the shortcoming that information is not available for all included countries and only for the years before 1993. In order to account for a possible dissolution of financial restrictions and a preference of staying at home we have also included GNP per capita of the sending country and its square. Controlling for the wage differential we thus expect a positive sign for GNP per capita and a negative one for its square. Because information about unemployment is only available for very few countries we try to capture the labor market situation in the LDCs by using the growth of Growth Domestic Product (GDP). We expect a negative effect of growth on migration flows.

Political factors potentially fostering emigration are captured here by the Freedom House Index for political rights and civil liberties, and the Political Terror Scale created by Purdue University, USA. Political rights in the context of the Freedom House Index enable people to participate in the political process, e.g. by free election of parliaments actually controlling governments in charge of public affairs, while civil liberties cover the freedom to express views, and to develop institutions and personal autonomy apart from the state, e.g., by freedom of speech, assembly or religion. For each of the two categories there is an index ranging from 1 (totally free) to 7 (not free at all) according to a checklist based on published source materials, reports from human rights organizations and governments, and newspapers. (For details see Freedom House 1991, pp. 1-54.) The overall Freedom House Index on human rights is the sum of the two single indicators. Although indices like this have been vastly criticized in the literature 
(e.g. Barsh, 1993), to us they seem an appropriate way to obtain at least some quantitative measure of freedom and the human rights situation in the sending countries. In order to capture the degree of actual political violence in a country rather than its general level of liberty, we also use the Political Terror Scale which ranks countries in five categories according to annual country reports by Amnesty International. Group 1 comprises countries with a secure rule of law, while group 5 contains countries where there is state violence against the whole population without limits on the means. For details see Gibney et al. (1996).

As described above, a major role in migration is ascribed to the existence of links between sending and host country. Networks facilitate information acquisition of potential migrants, as well as their adaptation to the new environment in the strange country of destination. In order to measure this effect, we include the number of persons of the same nationality residing in Germany at the beginning of the year as an explanatory variable. Another variable is the volume of trade between the sending country and Germany, i.e. the sum of exports and imports. We want to test the hypothesis that intensified economic contacts lead to an improved information flow and thus to lower migration and search costs. (For the same reason we also include the development aid flows from Germany to each country.) One has to mention here that this variable certainly does not allow an assessment of substitutionality or complementarity of trade and migration. This is because we control for the economic situation (income, growth) which is caused in part by trade. Moreover, in order to capture the effects of trade it would be in principle necessary to find a specification containing the overall volume of trade of the LDC and total emigration as well.

Another set of variables is to cover certain characteristics of the sending country. First, it is reasonable to control for population growth according to the theoretical direct and indirect effects of demographic change as explained above. Since population growth becomes effective 
via the labor market, we include the growth of labor force in our estimations. An increase of labor supply also tends to result in lower wages and possibly in higher unemployment. We have already controlled for this effect, however, by the variables GNP per capita and growth of GDP. Furthermore, one may expect that with advancing industrialization and the corresponding migration from the countryside into the cities, international migration will also rise. To account for this effect we include the share of urban population in total population.

A very common measure to control for the direct costs of migration is the use of distance between sending and destination country as a proxy. We suppose, however, that the explanatory power of this variable will not be very high since in our data set migratory movements take place over at least one thousand of kilometers. Direct costs like flight tickets should not vary that much for higher distances. Because distance is a country-specific and time-invariant variable it is only possible to include it in random effects and pooled OLS estimations.

Among further control variables there are dummies for restrictive legal measures taken in Germany in 1987, 1991 and 1993. From a formal point of view, the toughest reforms took place in 1993, with the change of the Basic Law. We expect that at least this dummy has a negative effect on migration flows. In principle, the 1991 reforms should result in a positive effect on migration. Finally, we include a time trend. Given that the other exogenous variables account for a multitude of time-dependent effects (e.g. by networks), it is to cover improved communication and transportation links due to technical progress. Table 1 gives a list of variables, their definition and descriptive statistics.

\section{Empirical results}

Before we have a detailed look at the estimation results in the third part of this section, we present several basic considerations of a more technical sort which nevertheless give some 
economically interesting conclusions. First, we deal with country-specific factors; second, we present the results of a sensitivity analysis.

\section{Unobserved country-specific determinants}

The decisive advantage of panel data over cross-sectional data is the possibility to control for country-specific factors. In order to test for existence of unobserved heterogeneity and thus for the necessity of a thorough panel analysis, we have made Breusch-Pagan tests (Breusch and Pagan, 1980). The tests take account of missing values creating an unbalanced panel which needs a special testing procedure (Baltagi and $\mathrm{Li}, 1990$ ). The test compares the random effects model to the pooled OLS model. If the variance of the country-specific error term introduced by the random effects approach is zero, this model has no additional explanatory power compared to a pooled OLS estimation. Given a critical value of 3.84 (the value of the $\chi^{2}$-distribution for the 95 per cent level of significance), the test statistics (Table 2) clearly indicate the existence of country-specific influences which are not covered by the explanatory variables. A BreuschPagan test has been done for all estimations in this paper and always favors the use of a random effects model, or at least of a panel model. Therefore, the test statistics have been omitted in the following tables which present the results of fixed effects estimations anyway.

This leads us to the question whether unobserved country-specific effects should be treated as random or as fixed parameters. Hausman's (1978) specification test explores if the unobserved heterogeneity is correlated with the explanatory variables. If the null hypothesis of zero correlation is refused a fixed effects model is preferred to a random effects model. Table 2 shows that the test statistics for our standard specification was 46.3 for total inflows and 50.1 for asylum immigration. Since the critical value for a significance level of 95 per cent is $23.69\left(\chi^{2}-\right.$ distributed), this is an unequivocal argument for the application of a fixed effects model. 
Thus there are country-specific determinants of the migratory movements which are not covered by the variables in our data set but are correlated with them. In order to possibly narrow down those determinants we take a closer look at the differences between the random and fixed effects estimations (Table 2). The estimated coefficients for the economic and political variables vary slightly but there is no difference in their statistical significance. Differences are more clearcut for the characteristics of the sending countries and for the institutional measures in Germany, but the most striking changes in the results refer to trade and development assistance. While these variables have a significantly positive impact on the magnitude of migration flows in the random effects model, they are insignificant in three of four cases in the fixed effects model. For migration of asylum seekers, trade with Germany has even a significantly negative influence on the migration rate.

It is interesting that it is these two variables intended to cover contacts to Germany, which seem particularly affected by unobserved country-specific influences. Further estimations reveal that introduction of a dummy variable for African sending countries massively reduces the value of the Hausman test statistics. Therefore we have run separate estimations for Africa and Asia. As one can see from Table 4 the test statistics do not contradict the random effects models any more in three of four cases (critical value: 23.69). Further distinctions of intra-continental regions do not improve the results any further.

Unobserved heterogeneity thus affects especially the contacts of sending and receiving countries, with the distinction between Africa and Asia playing an important role. Taking account of this aspect leads us to a possible theoretical or institutional explanation: The African continent may be roughly divided in two macro regions, i.e. the north African (mostly Arab or Muslim) countries and the sub-Saharian (mostly Black African) countries. In comparison to the Asian countries, both regions have special ties to the European Union and thus to Germany. The 
north African countries were in part sending countries within the framework of guestworker recruitment until the early 1970s; moreover, there have been a number of association agreements between the EU and the Mediterranean countries in the recent decades, most recently the Mediterranean Agreement of 1995. The sub-Saharian countries are associated to the EU via the Lomé agreements. Central parts of all those agreements with the African countries concern cooperation in trade, direct investment and development assistance.

Obviously, these special Afro-European relations have an impact on migration which is not fully covered by our data set, but also results in economic ties which distort the random effects estimations. From another perspective, trade and development aid do not seem perfect proxies for contacts between Germany and the sending countries. Information flows that are actually not directly connected to economic ties might be e.g. increasing reports about Europe and Germany in the media. They are not incorporated in our variables but may nevertheless be correlated with trade and are partly covered by the trade variable in the random effects model.

Even though there is no statistical evidence for some bias in the random effects estimations in each case, especially after splitting the data set in African and Asian subsamples, Tables 3 and 4 present only the results of our fixed effects estimations in order to keep consistency. The values of the Hausman test statistics as well as $\mathrm{R}^{2} \mathrm{~s}$ are given at the end of each column. For potential disadvantages of the fixed effects against the random effects approach, which are not relevant here, see e.g. Hsiao (1995).

\section{Robustness of estimation results}

We have also performed a sensitivity analysis by including and excluding variables and comparing the estimation results with our reference estimations (Table 2, (3) and (6)), in order to examine the robustness of our results. Moreover, it should give us hints for potential 
misspecifications and collinearity.

As explained in the previous part, unobserved heterogeneity plays an important role in particular with regard to information flows between Germany and the sending countries. Therefore it seems obvious to remove the variables intended to cover those contacts from the standard specification in a first step. Table 3 ((2) and (5)) shows that exclusion of trade with Germany and development aid to the sending countries leaves the coefficients of the other variables almost unchanged. Most interestingly, the Hausman test statistics falls extremely, to 24.5 for total inflows and even to 14.0 for asylum migration. This gives us another indication of unobserved country-specific effects being mainly correlated with contacts to the destination country and biasing their coefficients of a random effects estimation.

In further estimations we have included the stock of migrants from the sending country in Germany. There is a potential problem that introducing this network variable may lead to biases, similar to inclusion of a lagged dependent variable. This might be the case if the stock of migrants has substantially been created by current conditions. Moreover, the variable is not part of the standard specification since missing data would have led to a loss of many observations in the data set. Table 3 (3) and (6) show the expected positive impact of networks on the migration rate. Signs and significance of the other variables have not changed, thus there is actually no bias we feared. Like trade and development aid the stock of migrants measures contacts between sending and receiving country. Referring to the considerations made above, it is remarkable that the Hausman test statistics rise extremely for total inflows as well as for asylum migration when this variable is included. Unobserved country-specific factors would therefore also bias the coefficient of the network variable as another proxy for information flows in a random effects estimation. 
As both political variables basically seem to cover similar conditions, another set of control estimations has excluded one of them each, in order to obtain hints at potential collinearity. The results are not reported in the tables since there were no substantial changes. The same holds for an exclusion of countries with a per capita income of more than USD 10,000. These relatively "wealthy" outliers have only a minor impact. One could only see that for total inflows exclusion of those countries increases the coefficient of squared per capita income and doubles the impact of growth. Other estimations which are not reported in the tables either, have examined whether simultaneous inclusion of a time trend and the period dummies for institutional shifts in Germany might cause collinearity problems. Exclusion of the trend variable, however, has had no substantial consequences neither for the institutional nor for the other variables.

\section{The results in detail}

The empirical results for our economic variables are in accordance with the theoretical considerations of this paper (Table 2, column 3). The wage differential has a positive impact on the magnitude of migration to Germany. A one per cent rise in the differential implies a increase in migration by 1.6 per cent. For a given income differential we have found an inverse u-shaped relationship between per capita income and migration. Rising migration at a low income level may be explained by the dissolution of financial restrictions. In the long run the effect of home preference is dominant, i.e. the higher valuation of income in the home country. Growth of GDP has a significantly negative influence on migration. A one percent increase in growth results in a reduction of migration by 1.2 per cent. This indicates that the labor market situation is of high relevance for the volume of migration.

Taking account of purchasing power parities (Table 2, column 3) leads to a stronger 
response of inflows to the income differential and to lower importance of home preference and growth. One should remember the above notes on PPPs here. Further estimation results show that asylum migration in general is far less determined by economic variables than total inflows (Table 2), although there is a higher coefficient for the income differential for asylum seekers. Another remarkable point is that the Asian influx is far less influenced by economic factors than the African one (Table 4). Moreover, men react more strongly than women (Table 4).

Concerning the political variables we find the interesting result that, contrary to the economic determinants, migration flows from Asia are affected more strongly than those from Africa. Looking at the variables in more detail reveals another important point: Total inflows have been higher the better the political situation, but there have been the more asylum seekers the higher the level of terror in the sending country (Table 2). It is interesting to see that political rights and civil liberties have no impact on asylum migration while terror is insignificant for total inflows. This seems somewhat surprising since inflows also contain asylum seekers, but may be explained by obviously existing antagonistic effects. In principle, more freedom seems to mean more freedom to migrate too. Less terror in the sending countries, however, leads to less migration, as expected. Again, men react more strongly to the political variables than women (Table 4).

As this paper has shown, there are some other important theoretical aspects concerning the consequences of development progress for migration apart from the dissolution of financial restrictions and home preferences. By including the growth of the labor force direct demographic effects on the labor market should be covered. The estimation results reveal, however, that this variable has no significant impact on migration to Germany (Table 2). More people thus do not automatically imply more migrants. The indirect effect via an increase of supply in the labor market and rising unemployment or falling wages has been covered by the economic variables. 
Therefore growth of the labor force only measures the direct effect. In order to grasp the impact of societal change on migration we have included the fraction of urban population in the estimations. There has been the expected positive effect on migration. For total inflows, a one per cent rise in the share of urban population means an increase of migrants by 2.7 per cent. For asylum seekers, the number is 2.9 per cent (Table 2). This may be explained by the higher mobility and better information of people living in the city. Moreover, human capital of urban, i.e. non-agricultural workers might be easier transferable to an industrialized country. The variable has a particularly strong effect for men and for flows from Africa (Table 4).

At the beginning of the section we have shown that trade and development aid are especially interesting with regard to country-specific effects. Within the framework of the estimations they have been intended as proxies for existing contacts and information flows which decrease migration costs and uncertainty. We have not found any significant effects for the total data set in three of four cases (Table 2). Distinguishing Africa from Asia (Table 4), however, has given us a hint at a more complicated relationship. Development aid remains insignificant but trade has a significantly positive effect for Asia, while its impact on African asylum seekers is significantly negative. The latter leads us to the conjecture that there might be two antagonistic effects. On the one hand, trade has the expected positive influence on migration to Germany because it improves information. This comes to bear in the case of Asia. On the other hand, trade might be negatively correlated with the political situation. This effect could be dominant in the case of Africa since economic relations to Germany (and Europe) are far more politically institutionalized. The estimations would then suggest a negative impact of trade on asylum migration although both variables are influenced by the bad political situation: trade falls and migration rises. Based on the same data set, Vogler (1999) has shown that regressing trade on the political situation reveals that, indeed, domestic terror in a sending country has significantly 
negative consequences for trade with Germany, while the Freedom House Index remains insignificant. This holds for Africa as well as (to a lower degree) for Asia. German development aid, however, is not influenced by the political situation.

In comparison to the purely descriptive observation that inflows and applications for asylum have decreased strongly after the reform years of 1987 and 1993, significance of the estimated coefficients for the institutional measures seems rather weak. Nevertheless the estimations have provided the expected pattern of a negative impact of the 1987 and 1993 reforms on migration to Germany, and of a positive one for the abolition of the temporary work ban in 1991 (Table 2). Weak significance, especially in the subsamples (Table 4), indicates that it is difficult to distinguish between the effects of the single measures. First, they are only few years apart, so there are only relatively few observations for the transition periods. Second, the actual effects overlap, so the positive effects of the 1991 reform, for example, have been still valid in 1993 and afterwards, after opposite measures had been taken.

Table 2 shows that distance variable has the expected strongly negative effect on migration. As usual it has been used as a proxy for migration costs, but could not be included in the fixed effects estimations since it covers a country-specific, time-invariant effect. Finally, in all fixed effects estimations there is no significant time trend which should have modeled improving infrastructure and communications technologies.

\section{Conclusions}

Empirical studies on international migration have so far neglected one important point. This paper has demonstrated that the theoretical literature provides a lot of aspects concerning the effects of development on migration which go far beyond the analysis of simple income differentials. Combining them leads to the hypothesis that even with persistently converging 
living standards, development progress in the Third World will result in an increase of migration to the industrialized countries in the short and medium run.

Our empirical analysis has found some interesting results. It has been based on a panel data set on migration to Germany from 86 countries in the years 1981 to 1995. Additional information has been available on migration of asylum seekers for 1984 to 1995 . We have found that flows from Africa respond more strongly to economic influences than those from Asia. The reverse pattern is valid for the political variables included. Moreover, men react more strongly than women in general, which might be due to the fact that women tend to come to Germany within the framework of family reunification.

Concerning the development-migration nexus our results indicate that, for given income differentials and low income in the sending countries progress in development will lead to higher migration. For higher incomes there is the reverse effect, which confirms the hypothesis that there is a home preference for potential migrants. Population growth which may be initiated by development, among other factors, has no direct effect on migration to Germany. Indirect effects of population growth via the labor market have been confirmed by the included economic variables. Societal change initiated by development has led to higher migration via an increasing share of urban population in the LDCs. The estimations have not revealed any significant effect of a time trend which indicates that progress in infrastructure and communications technologies since the 1980s has had no impact per se on migration from the LDCs to Germany.

The empirical results also confirm that there are country-specific determinants of migration beyond the influence of networks and other information flows through trade and development assistance. The various institutional variables have provided the expected results. The restrictive measures of 1987 and 1993 have indeed had a negative effect on migration, while 
the abolition of the temporary work ban in 1991 has had a positive one. 


\section{References}

Bähr J, Jentsch C, Kuls W (1992) Bevölkerungsgeographie. De Gruyter, Berlin.

Baltagi BH, Li Q (1990) A Lagrange multiplier test for the error components model with incomplete panels. Econometric Reviews 9: 103-107

Barsh, RL (1993) Measuring human rights: problems of methodology and purpose. Human Rights Quarterly 15:87-121

Bauer T, Zimmermann KF (1995) Modeling international migration: economic and econometric issues. In: van der Erf R, Heering L (eds) Causes of International Migration. Proceedings of a Workshop, Luxembourg, 14.-16.December 1994. Eurostat, Luxembourg, 95-115

Breusch TS, Pagan AR (1980) The Lagrange multiplier test and its application to model specification in econometrics. Review of Economic Studies 47:239-253

EUROSTAT (various issues) Migration Statistics. Eurostat, Luxembourg.

Faini R, Venturini A (1993) Trade, aid and migrations. European Economic Review 37:435-442

Freedom House (1991) Freedom in the World: Political Rights and Civil Liberties 1990-1991. Freedom House, New York

Ghatak S, Levine P, Price SW (1996) Migration theories and evidence: An assessment. Journal of Economic Surveys 10:159-198

Gibney M, Apodaca C, McCann J (1996) Refugee flows, the internally displaced and political violence (1980-1993): an exploratory analysis. In: Schmid AP (ed) Whither Refugee? Human Rights Violations and Refugees: Causes and Consequences. LISWO, Leiden

Goodwin-Gill G (1989) International law and human rights: Trends concerning international migrants and refugees. International Migration Review 23:526-546

Hatton TJ, Williamson JG (1994) What drove the mass migrations from Europe?. Population and Development Review 20:533-559

Hausman JA (1978) Specification tests in econometrics. Econometrica 46:1251-1271

Hicks J (1932) The Theory of Wages. MacMillan, London

Hsiao C (1995) Analysis of Panel Data. Cambridge University Press, Cambridge

ILO (1997) International Migration Statistics. International Labour Office, Geneva

Massey DS (1988) Economic development and international migration in comparative perspective. Population and Development Review 14:383-413

Massey DS, Arango J., Hugo G, Kouaouci A, Taylor JE (1993) Theories of international 
migration: A review and appraisal. Population and Development Review 19:431-466.

Segal A (1993) An Atlas of International Migration. Hans Zell Publishers, London.

Sjaastad LA (1962) The costs and returns of human migration. Journal of Political Economy 70:80-93

SOEC (1985) A comparision of purchasing power parities and real economic aggregates in fifteen African countries. Statistical Journal of the United Nations Economic Commission for Europe 3:17-32

SOPEMI (various issues) Trends in International Migration. OECD, Paris

Stark O, Bloom DE (1985) The new economics of labor migration. American Economic Review Papers and Proceedings 75:173-178

Straubhaar T (1988) On the Economics of International Labor Migration. Verlag Paul Haupt, Bern

Summers R, Heston A (1991) The Penn World Table (Mark 5): An expanded set of international comparisons, 1950-1988. Quarterly Journal of Economics 106:327-68

U.S. Commission (1991) Immigration and economic development. In: Papademetriou DG, Martin PL (eds.) The Unsettled Relationship: Labor Migration and Economic Development. Greenwood Press, Westport, 221-241

Vogler M (1999) Determinanten der Zuwanderung aus Entwicklungsländern. Forthcoming: Nomos, Baden-Baden

World Bank (1999) World Development Report 1998/99. The World Bank, Washington 
Table 1. Variables and Descriptive Statistics

\begin{tabular}{|c|c|c|}
\hline Variable & Definition & $\begin{array}{c}\text { Mean } \\
(\text { Std.dev.) }\end{array}$ \\
\hline \multicolumn{3}{|l|}{ Economic variables } \\
\hline In Income differential & $\begin{array}{c}\text { In (GNP per capita Germany / GNP per capita sending } \\
\text { country) }(1987=100)\end{array}$ & $\begin{array}{l}3.11 \\
(1.3)\end{array}$ \\
\hline In Income per capita & ln (GNP per capita sending country) $(1987=100)$ & $\begin{array}{l}6.6 \\
(1.3)\end{array}$ \\
\hline ln PPP differential & ln (PPP Germany / PPP sending country) & $\begin{array}{l}2.14 \\
(0.9)\end{array}$ \\
\hline $\ln$ PPP & ln (PPP sending country) & $\begin{array}{l}2.2 \\
(0.9)\end{array}$ \\
\hline Growth & Growth of Real GDP of sending country & $\begin{array}{c}3.3 \\
(6.6)\end{array}$ \\
\hline \multicolumn{3}{|l|}{ Political situation } \\
\hline Political rights, civil liberties & $\begin{array}{l}\text { Combined Freedom House Index for sending country: } 2 \\
\text { (free) - } 14 \text { (not free) }\end{array}$ & $\begin{array}{l}10.52 \\
(2.9)\end{array}$ \\
\hline Political terror scale & $\begin{array}{l}\text { Scale for sending country according to Amnesty } \\
\text { International: } 1 \text { (no terror) -5 (terror without limits) }\end{array}$ & $\begin{array}{l}2.95 \\
(1.0)\end{array}$ \\
\hline \multicolumn{3}{|c|}{ Other characteristics of sending countries } \\
\hline Growth of labor force & Annual growth of labor force (in \%) of sending country & $\begin{array}{l}1.61 \\
(2.9)\end{array}$ \\
\hline Ln Share of urban population & In (Share of urban population of sending country) & $\begin{array}{l}3.44 \\
(0.6)\end{array}$ \\
\hline Ln Distance & $\begin{array}{l}\text { In (Shortest distance between borders of sending county } \\
\text { and Germany (in } \mathrm{km}) \text { ) }\end{array}$ & $\begin{array}{l}8.49 \\
(0.5)\end{array}$ \\
\hline \multicolumn{3}{|l|}{ Contacts to Germany } \\
\hline In Trade with Germany (rate) & $\begin{array}{l}\text { In (Sum of the sending countries exports to and imports } \\
\text { from Germany / population of sending country) }\end{array}$ & $\begin{array}{l}-8.50 \\
(3.6)\end{array}$ \\
\hline ln Aid from Germany (rate) & $\begin{array}{c}\text { Ln (Official development aid for sending country from } \\
\text { Germany /population of sending country) }\end{array}$ & $\begin{array}{l}-9.23 \\
(4.4)\end{array}$ \\
\hline In Population in Germany & $\begin{array}{l}\text { In (Stock of nationals of the sending country in Germany at } \\
\text { the beginning of the period) }\end{array}$ & $\begin{array}{l}7.65 \\
(2.1)\end{array}$ \\
\hline \multicolumn{3}{|l|}{ Institutional Measures } \\
\hline Change of law 1987 & Change of law in Germany: $1=$ after 1987 ; 0 before & $\begin{array}{l}0.60 \\
(0.5)\end{array}$ \\
\hline Change of law 1991 & Change of law in Germany: $1=$ after $1991 ; 0$ before & $\begin{array}{l}0.27 \\
(0.4)\end{array}$ \\
\hline Change of law 1993 & Change of law in Germany: $1=$ after 1993 ; 0 before & $\begin{array}{l}0.13 \\
(0.3)\end{array}$ \\
\hline
\end{tabular}

Notes: ln: natural logarithm; Inflow from 49 African and 37 Asian countries. Period 19811995 (asylum migration 1984-1995).

Sources: German Federal Ministry of the Interior, German Federal Statistical Office, World Bank, Development Assistance Committee, Freedom House, PIOOM. 
Table 2. Pooled OLS, Fixed Effects, Random Effects

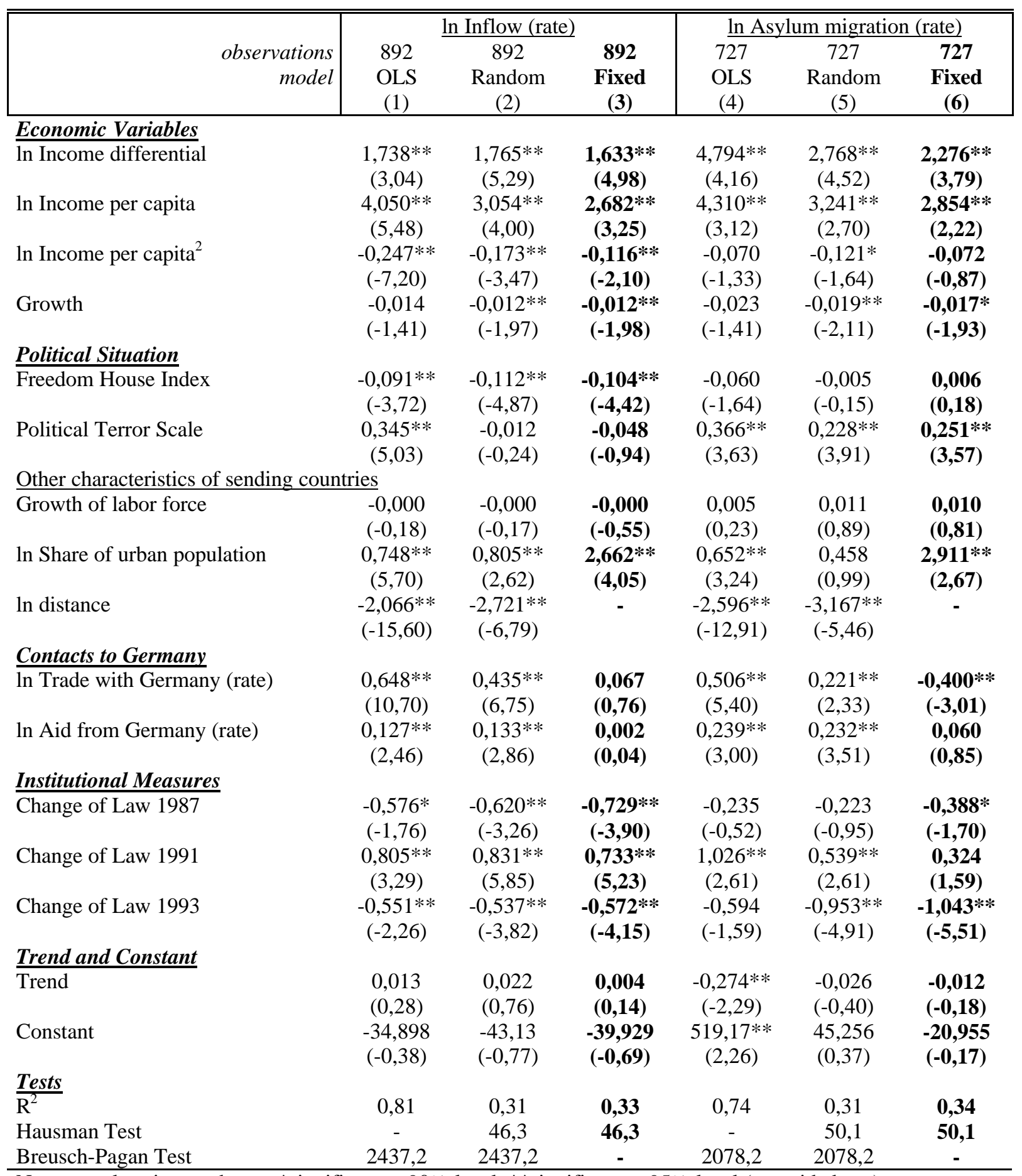

Notes: t-values in paratheses; *significant at 90\%-level, **significant at 95\%-level (two-sided test). 
Table 3. Different specifications

\begin{tabular}{|c|c|c|c|c|c|c|}
\hline \multirow[b]{2}{*}{ observations } & \multicolumn{3}{|c|}{ Ln Inflows (rate) } & \multicolumn{3}{|c|}{$\underline{\text { ln asylum migration (rate) }}$} \\
\hline & $\begin{array}{l}733 \\
(1)\end{array}$ & $\begin{array}{l}896 \\
(2)\end{array}$ & $\begin{array}{l}672 \\
(3)\end{array}$ & $\begin{array}{l}595 \\
(4)\end{array}$ & $\begin{array}{c}730 \\
(5)\end{array}$ & $\begin{array}{c}525 \\
(6)\end{array}$ \\
\hline \multicolumn{7}{|l|}{ Economic Variables } \\
\hline$\overline{\text { ln Income differential }}$ & $1,282 * *$ & $1,560 * *$ & $8,608 * *$ & $2,244 * *$ & $2,517 * *$ & $8,224 * *$ \\
\hline (3) (6): $\ln$ PPP-relation & $(4,15)$ & $(4,91)$ & $(7,33)$ & $(3,55)$ & $(4,22)$ & $(3,38)$ \\
\hline ln Income per capita & $3,362 * *$ & $2,560 * *$ & $7,379 * *$ & $2,475^{*}$ & $3,283 * *$ & 3,184 \\
\hline (3) (6): $\ln$ PPP & $(4,46)$ & $(3,16)$ & $(5,82)$ & $(1,85)$ & $(2,58)$ & $(1,17)$ \\
\hline ln Income per capita ${ }^{2}$ & $-0,158 * *$ & $-0,105^{*}$ & 0,128 & $-0,020$ & $-0,105$ & $0,633 * *$ \\
\hline (3) (6): $\ln \mathrm{PPP}^{2}$ & $(-3,11)$ & $(-1,94)$ & $(1,40)$ & $(-0,23)$ & $(-1,30)$ & $(2,83)$ \\
\hline Growth & $\begin{array}{c}-0,020 * * \\
(-3,29)\end{array}$ & $\begin{array}{c}-0,012 * * \\
(-1,97)\end{array}$ & $\begin{array}{l}-0,007 \\
(-1,44)\end{array}$ & $\begin{array}{c}-0,018^{*} \\
(-1,73)\end{array}$ & $\begin{array}{c}0,019 * * \\
(-2,15)\end{array}$ & $\begin{array}{c}-0,017^{*} \\
(-1,68)\end{array}$ \\
\hline \multicolumn{7}{|l|}{ Politische Situation } \\
\hline$\overline{\text { Freiheitsindex }}$ & $\begin{array}{c}-0,073 * * \\
(-3,47)\end{array}$ & $\begin{array}{c}-0,103 * * \\
(-4,42)\end{array}$ & $\begin{array}{c}-0,074 * * \\
(-2,73)\end{array}$ & $\begin{array}{l}0,040 \\
(1,16)\end{array}$ & $\begin{array}{l}-0,000 \\
(-0,01)\end{array}$ & $\begin{array}{c}-0,083 * \\
(-1,80)\end{array}$ \\
\hline Terrorskala & $\begin{array}{l}-0,042 \\
(-0,82)\end{array}$ & $\begin{array}{l}-0,052 \\
(-1,01)\end{array}$ & $\begin{array}{l}-0,063 \\
(-1,34)\end{array}$ & $\begin{array}{c}0,189 * * \\
(2,46)\end{array}$ & $\begin{array}{c}0,271 * * \\
(3,88)\end{array}$ & $\begin{array}{c}0,131 * \\
(1,69)\end{array}$ \\
\hline \multicolumn{7}{|c|}{ Other characteristics of sending countries } \\
\hline Growth of labor force & $\begin{array}{c}0,000 \\
(-0,01)\end{array}$ & $\begin{array}{l}-0,000 \\
(-0,62)\end{array}$ & $\begin{array}{l}-0,000 \\
(-0,55)\end{array}$ & $\begin{array}{l}0,002 \\
(0,15)\end{array}$ & $\begin{array}{l}0,009 \\
(0,80)\end{array}$ & $\begin{array}{l}0,014 \\
(1,30)\end{array}$ \\
\hline In Share of urban population & $\begin{array}{c}2,688 * * \\
(3,89)\end{array}$ & $\begin{array}{c}2,752 * * \\
(4,26)\end{array}$ & $\begin{array}{c}2,303 * * \\
(3,25)\end{array}$ & $\begin{array}{c}3,541 * * \\
(2,76)\end{array}$ & $\begin{array}{c}3,047 * * \\
(2,82)\end{array}$ & $\begin{array}{l}-0,323 \\
(-0,20)\end{array}$ \\
\hline \multicolumn{7}{|l|}{ Contacts to Germany } \\
\hline In Trade with Germany (rate) & $\begin{array}{l}0,006 \\
(0,08)\end{array}$ & - & $\begin{array}{l}0,023 \\
(0,27)\end{array}$ & $\begin{array}{c}-0,521 * * \\
(-3,66)\end{array}$ & - & $\begin{array}{c}-0,428 * * \\
(-2,64)\end{array}$ \\
\hline ln Aid from Germany (rate) & $\begin{array}{l}-0,011 \\
(-0,20)\end{array}$ & - & $\begin{array}{l}0,018 \\
(0,38)\end{array}$ & $\begin{array}{l}0,091 \\
(1,08)\end{array}$ & - & $\begin{array}{l}-0,052 \\
(-0,63)\end{array}$ \\
\hline In Population in Germany & $\begin{array}{c}0,542 * * \\
(5,07)\end{array}$ & - & - & $\begin{array}{c}1,280 * * \\
(7,59)\end{array}$ & - & - \\
\hline \multicolumn{7}{|l|}{ Institutional Measures } \\
\hline Change of Law 1987 & $\begin{array}{c}-0,602 * * \\
(-3,44)\end{array}$ & $\begin{array}{c}-0,755^{* *} \\
(-4,10)\end{array}$ & $\begin{array}{c}-0,375^{* *} \\
(-3,14)\end{array}$ & $\begin{array}{l}-0,324 \\
(-1,34)\end{array}$ & $\begin{array}{l}-0,303 \\
(-1,33)\end{array}$ & $\begin{array}{l}-0,205 \\
(-1,05)\end{array}$ \\
\hline Change of Law 1991 & $\begin{array}{c}0,327 * * \\
(2,40)\end{array}$ & $\begin{array}{c}0,721 * * \\
(5,19)\end{array}$ & $\begin{array}{c}0,724 * * \\
(4,89)\end{array}$ & $\begin{array}{l}-1,146 \\
(-0,65)\end{array}$ & $\begin{array}{c}0,392^{*} \\
(1,94)\end{array}$ & $\begin{array}{c}0,535 * * \\
(2,40)\end{array}$ \\
\hline Change of Law 1993 & $\begin{array}{c}-0,640 * * \\
(-4,90)\end{array}$ & $\begin{array}{c}-0,578 * * \\
(-4,19)\end{array}$ & - & $\begin{array}{c}-1,110 * * \\
(-5,43)\end{array}$ & $\begin{array}{c}-1,022^{* * *} \\
(-5,38)\end{array}$ & - \\
\hline \multicolumn{7}{|l|}{ Trend and Constant } \\
\hline$\overline{\text { Trend }}$ & $\begin{array}{l}-0,016 \\
(-0,54)\end{array}$ & $\begin{array}{l}0,005 \\
(0,17)\end{array}$ & $\begin{array}{c}0,021 \\
(-0,81)\end{array}$ & $\begin{array}{l}-0,086 \\
(-1,23)\end{array}$ & $\begin{array}{l}-0,037 \\
(-0,57)\end{array}$ & $\begin{array}{l}0,105 \\
(1,61)\end{array}$ \\
\hline Constant & $\begin{array}{l}-6,830 \\
(-0,12)\end{array}$ & $\begin{array}{l}-42,36 \\
(-0,73)\end{array}$ & $\begin{array}{l}-6,813 \\
(-0,14)\end{array}$ & $\begin{array}{c}115,72 \\
(0,86)\end{array}$ & $\begin{array}{l}29,39 \\
(0,24)\end{array}$ & $\begin{array}{c}-247,77 * * \\
(-2,06)\end{array}$ \\
\hline Tests & & & & & & \\
\hline$\overline{\mathrm{R}^{2}}$ & 0,36 & 0,34 & 0,35 & 0,45 & 0,33 & 0,42 \\
\hline Hausman Test & 124,8 & 24,5 & 48,55 & 100,4 & 14,0 & 164,3 \\
\hline
\end{tabular}

Notes: Fixed Effects Estimations; t-values in paratheses; Changes related to the reference estimations: (1)(4)

Consideration of population stock in Germany; (2)(5) Cancellation of trade and aid, (3)(6) Income variables in PPP; *significant at 90\%-level, **significant at 95\%-level (two-sided test). 
Table 4: Men and Women, Africa und Asia

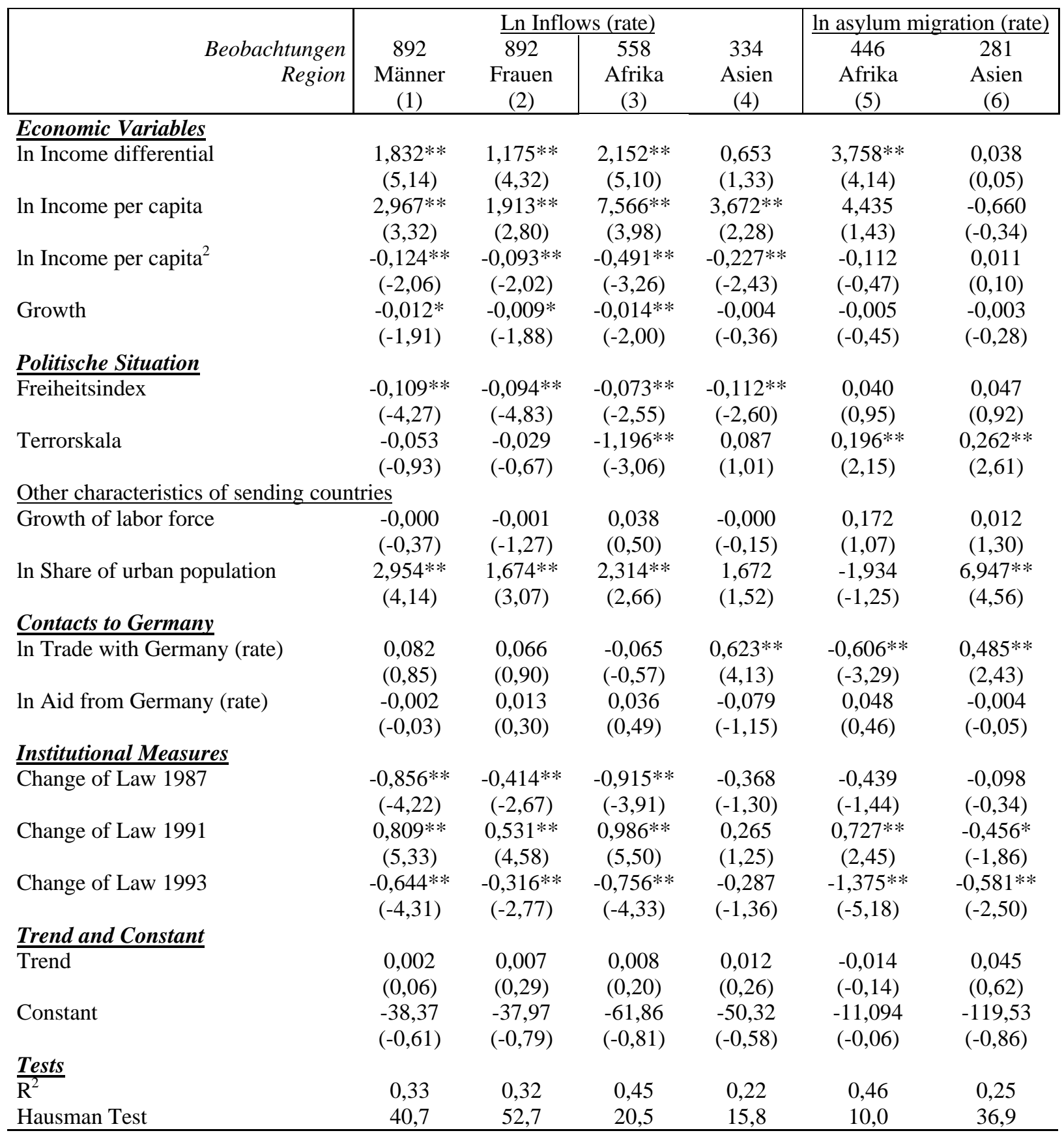

Notes: fixed effects estimations; t-values in paratheses; *significant at 90\%-level, **significant at $95 \%$-level (two-sided test). 
Figure 1: Inflows to Germany (1960-1997)

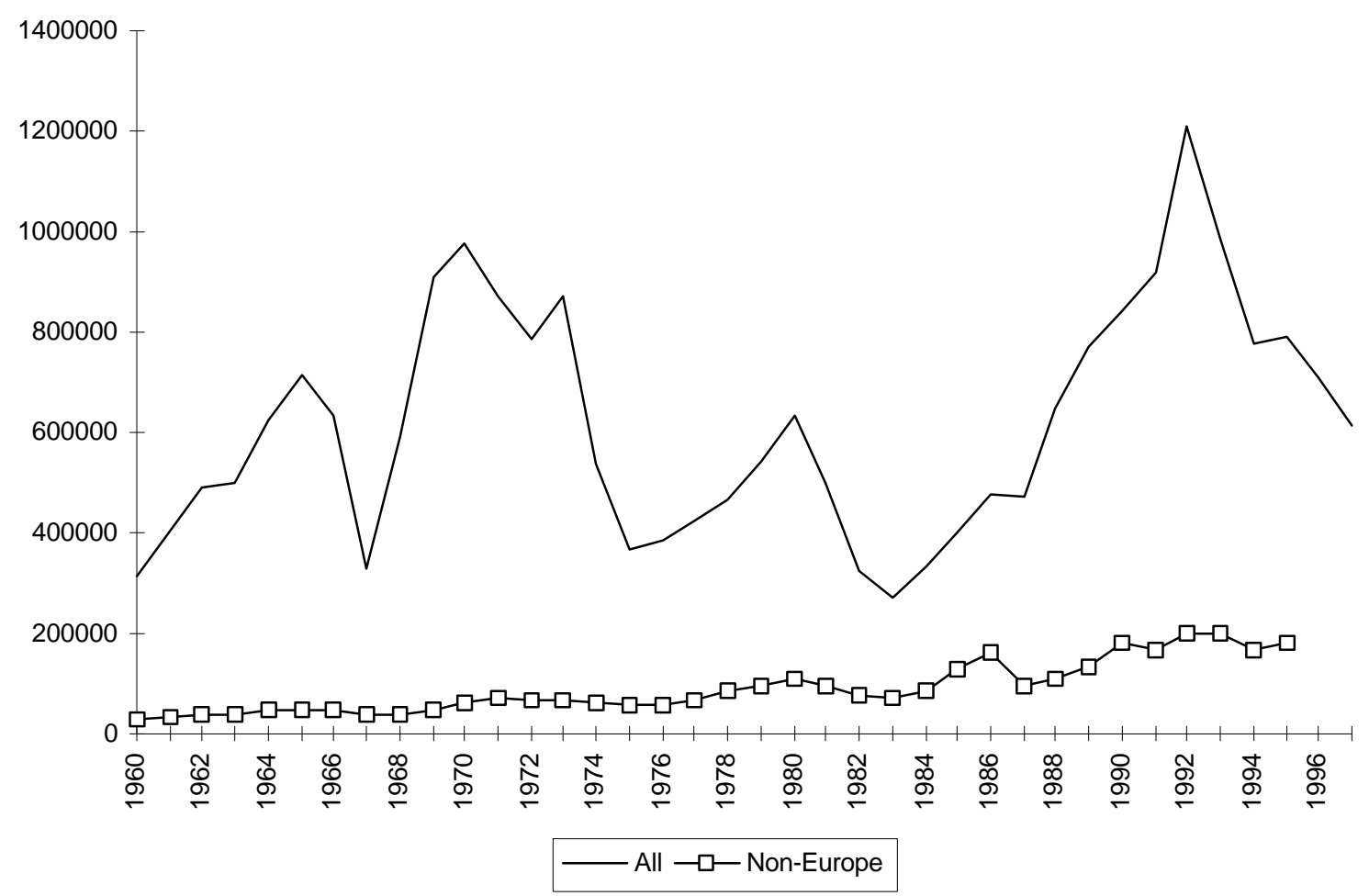

Note: Immigration of foreigners.

Source: German Federal Statistical Office 
Figure 2: Inflows to Germany by continents (1960-1995)

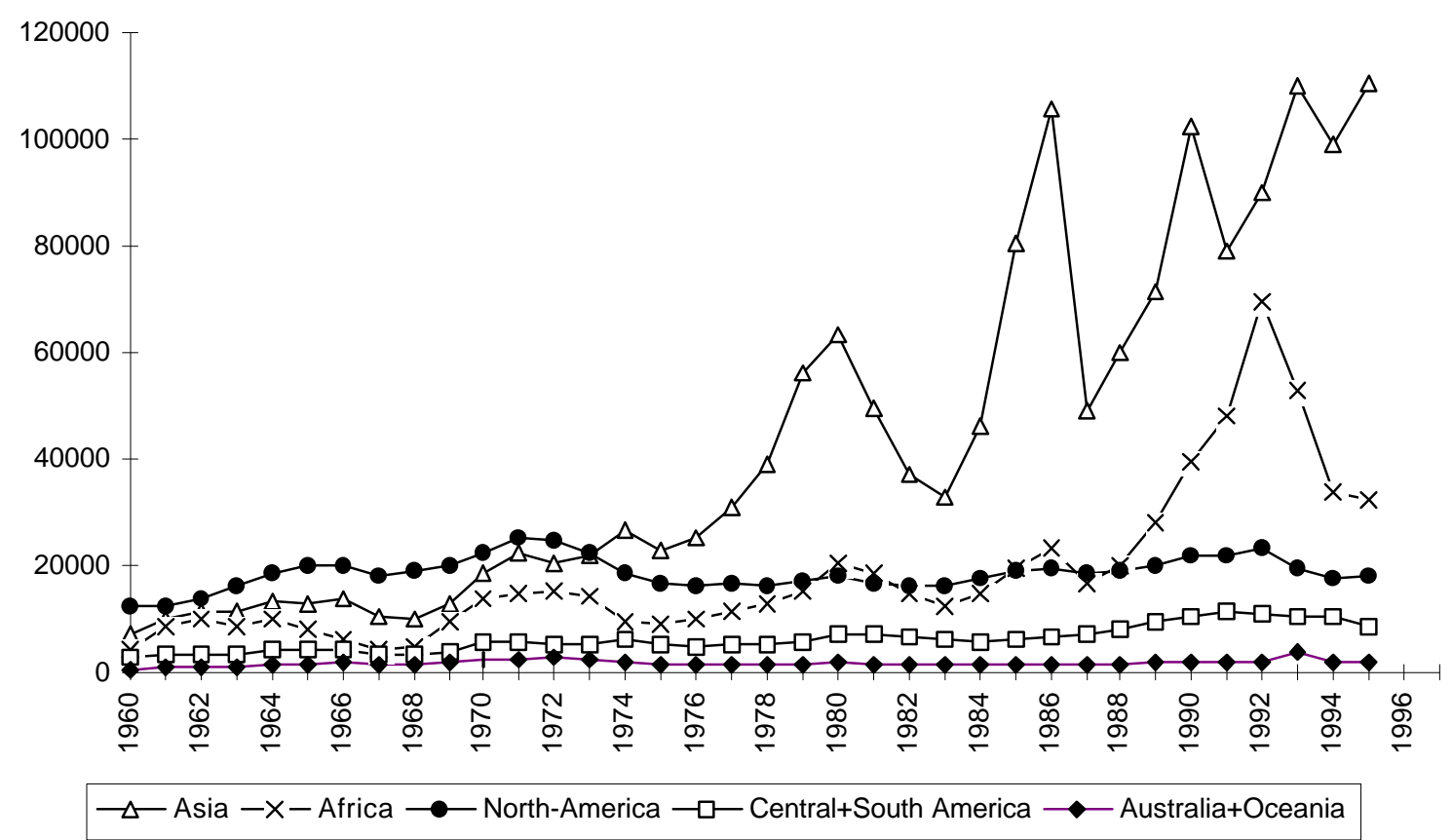

Note: Immigration of foreigners; Europe: see balance in Figure 1.

Source: German Federal Statistical Office 
Figure 3: Asylum seekers in Germany (1965-1996)

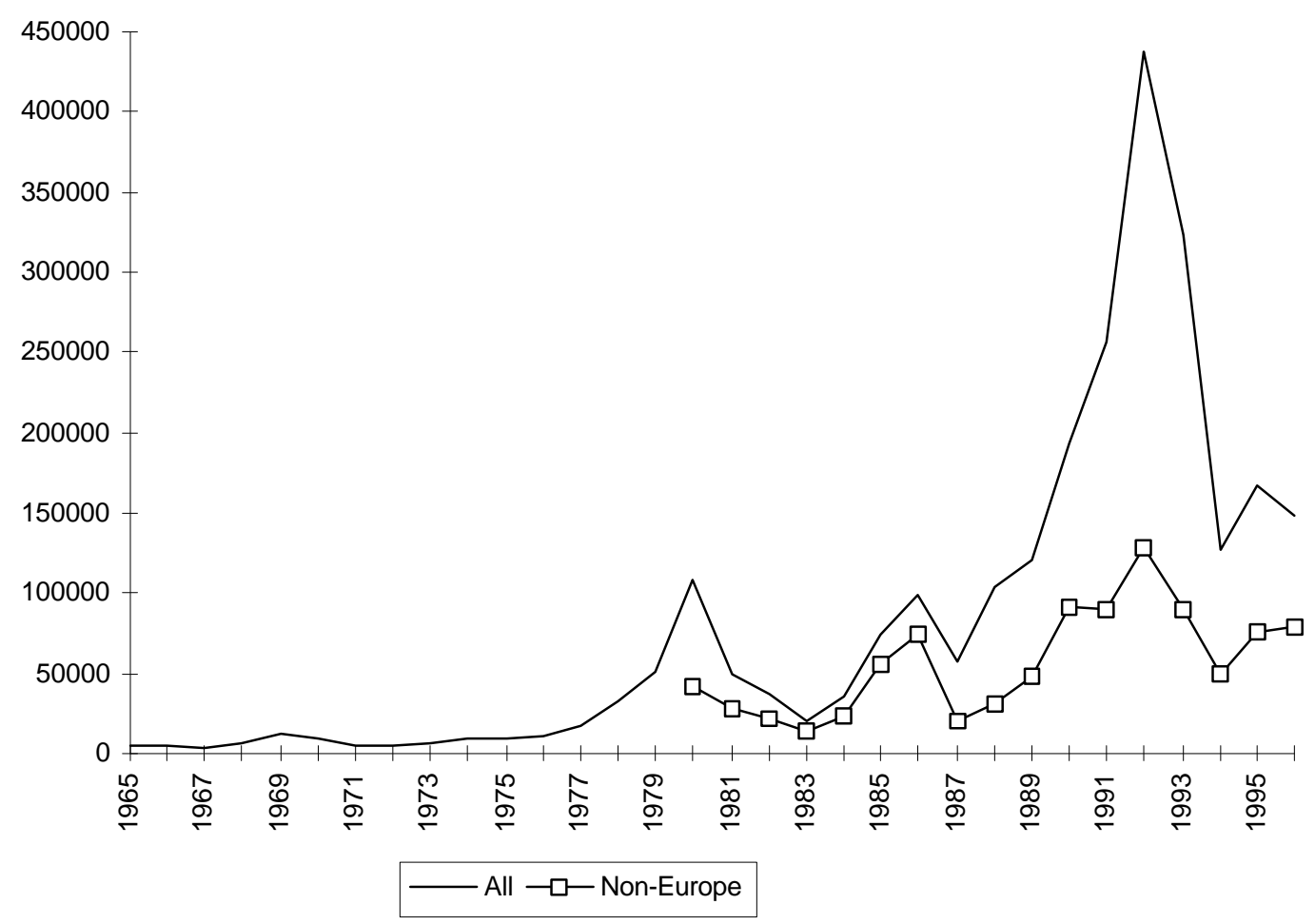

Note: Number of asylum applications.

Source: German Federal Ministry of the Interior 
Figure 4: Asylum seekers in Germany by continents (1980-1996)

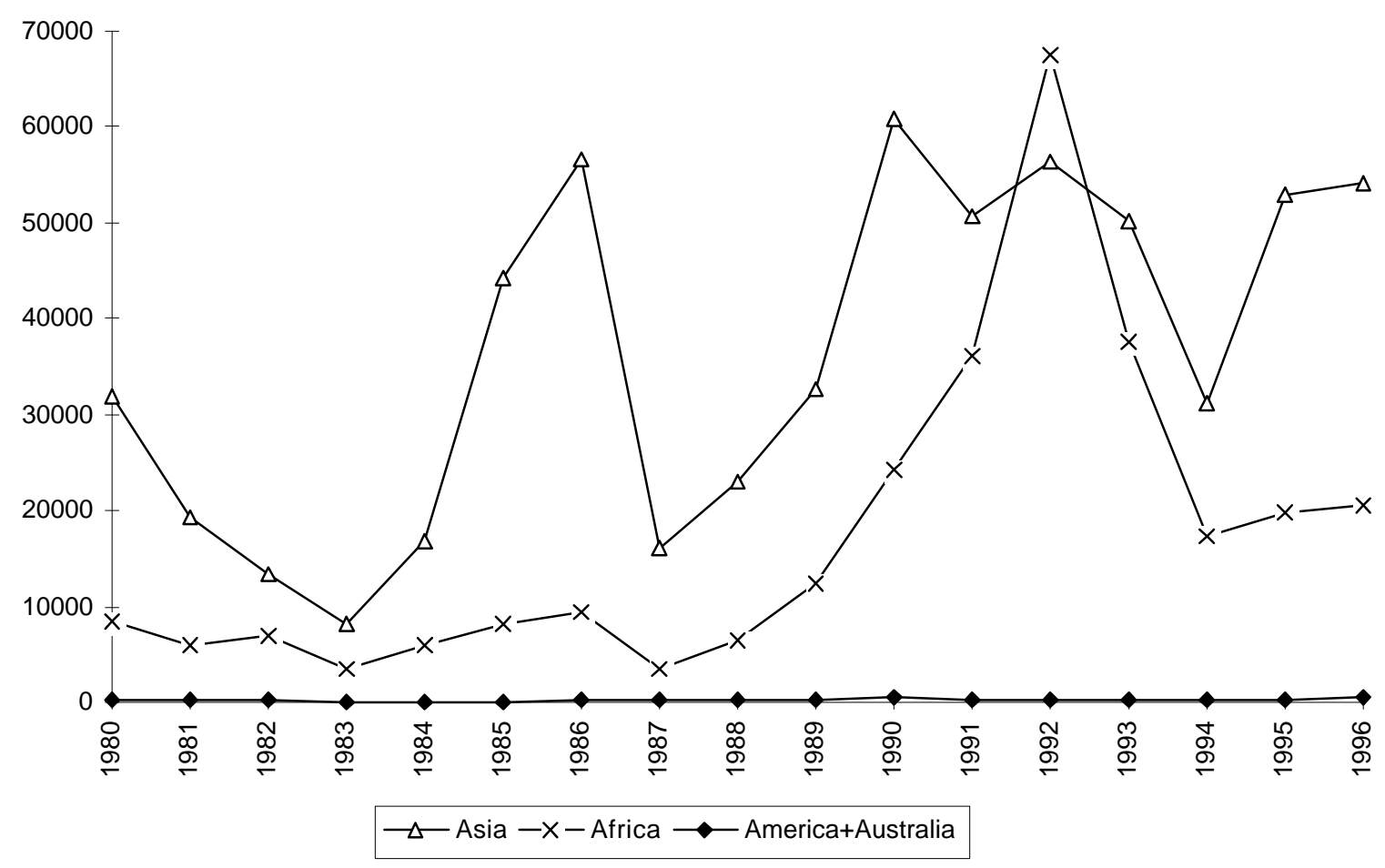

Notes: Number of asylum applications; Europe: see balance in Figure3.

Source: German Federal Ministry of the Interior 